\title{
News agencies in the era of globalization and new challenges of reality
}

\author{
Kanat Kulshmanov \\ $\mathrm{PhD}$ doctoral student of L.N. Gumilyov \\ Eurasian National University, Astana, Kazakshtan \\ E-mail: zk87@mail.ru \\ Assima Ishanova \\ Doctor of philological sciences, professor of L.N. Gumilyov \\ Eurasian National University, Astana, Kazakshtan \\ E-mail: ishanova87@mail.ru
}

DOI:10.5901/mjss.2014.v5n19p48

\begin{abstract}
The article deals with features of functioning of news agencies in terms of postmodern situation. There is a comparison of traditional and new principles of work, identification of new trends and issues (information pollution, "digital division", framing of news, shadow fusion with PR and advertising) in development of news agencies in the context of challenges of global media. The system of modern media news agencies initially occupy a special place as the main suppliers of information to the media, but with the advent of the Internet they have an opportunity of direct contact with the audience, and many other new features that have significantly changed their qualitative characteristics.

News agencies of Kazakhstan and Russia today differ by a number of new features of functioning: multimediality, online news, multi-channel availability, multilingual texts, and a growing number of subscribers.

Functioning of modern news agencies is considered from the standpoint of ethical, technological and social transformations, among which a particular role is given to the problem glocalization, perception of information, press realization of media, the growth of new information intermediaries, universal gadgetization, cross -, trans- and multimediality, virtualization of global brands, inclination for news flashes.
\end{abstract}

Keywords: news agencies, simulacrum, framing, information, advertising, multimedia, information pollution

\section{Introduction}

Modern researchers are talking about a serious crisis of the media, significant changes in the very system of media, primarily associated with the digital revolution, technological and civilizational shifts.

News agencies in modern conditions also vary considerably and these processes are still poorly understood. Many researchers have noted that today there in an obvious trend, manifested in all varieties of mass media - journalism has lost the monopoly on news, the position and authority of professional journalists have considerably weakened, and there is a kind of media framing of reality [Vartanova, 2013]. Meanwhile, exactly news is traditionally considered as a prime product of news agencies. What changes have occurred in the structure and functional priorities of agencies? Can news agencies of the post-Soviet countries compete with influential international world agencies that have a long history of development? These questions can be explained by considering a pre-set of issues related to the new trends in the development of news agencies.

It is difficult to deny that we are today fully under the influence of the reality produced by mass media. The product of news agencies in a more visible manner demonstrates the ability of the media with support of the principle of simulacrum to create your own reality out of tracks. The war in Iraq or Afghanistan is presented to us, it would seem, in real time, exactly as we see it (on TV), or just the way we read about it in the news agencies. But all that is left over or behind the text, as it were, do not exist, and it becomes the basis of media framing of reality. 
News agencies as well as all media now actively construct some different reality which seems simultaneously more real than reality itself.

Jean Baudrillard [1981] in his works emphasized the ability of the media to increase the total effect of simulation of reality. The scientist concludes that the media have neutralized reality.

In his work "Reality as a Subject of Negotiations" David Everett Willock [2000, 22] notes that we live in a world where cultures create attractors of postmodern times, "where new technologies constantly construct discourses on any topic, whereas real communication is becoming less".

In the system of modern media news agencies have initially occupied a special place as the main suppliers of information to the media, but with the advent of the Internet they have an opportunity of direct contact with the audience and many other new features that have significantly changed their qualitative characteristics.

Modern news appears first in digital format, and only later - in print, so the trend of news agencies is particularly relevant today.

If five or six years ago in Kazakhstan it was debated whether online editions can be referred to the media, today namely online journalism is the most demanded and popular thanks to smartphones and tablets.

In the present situation, the least vulnerable seems the path of development of news agencies. It happened because news agencies earlier and faster than other varieties of media have adapted to Internet resources, have expanded their content and have adopted to the new varieties of news texts. Ways of presenting the material have also become much more attractive for users - and infographics and video, and a variety of high-quality photos. Many international news agencies still retain their leadership - Xinhua, Kyodo Tsushin, Agence France-Presse and others, in Russia there are new leaders of news agencies - these are RIA-Novosti, Interfax, and RBC. Moreover these Russian news agencies today are noticeably progressing and justifiably claim to the role of international news agencies.

Kazakhstan has in recent decades added to the already existing (Kazinform) news agencies new ones, branches of Russian agencies, and their activity is developing in various directions and thus they basically complement each other: these are Tengrinews, BNews, Novosti-Kazakhstan, Interfax-Kazakhstan, KazTAG, Information and Analytical Portal of Kazakhstan, KursivKZ, Today in Kazakhstan, Kazakhstan Today and others.

\section{New features in functioning of news agencies}

News agencies of Kazakhstan and Russia today distinguish themselves by a number of new features of functioning: multimedia, online news, multi-channel availability, multilingual texts, a growing number of subscribers.

At the same time, in modern conditions, there is a decrease in quality of information flow, it seems that the source of information for news every day becomes considerably scanty. Therefore, news agencies are supported in major countries of the world where they are perceived as a kind of image brands of a country. Many of the known world news agencies are currently covertly receiving significant financial subsidies from the governments of their countries (Reuters, Associated Press, etc.) [Strashnov, 2012, 60].

There is another important new trend: some news agencies began to prepare specific applications (programs), news releases for modern smartphones called iphones and tablets. In tablets and iphones you can easily read feeds of Tengrinews, BNews, BBC News, Reuters, Vesti, Euronews, RIA Novosti, Rambler. This greatly increases the popularity of websites of news agencies.

But, of course, the main active consumers of media products of news agencies are TV channels, newspapers and magazines. To see it, just watch the evening news broadcasts of any of the channels in Kazakhstan or Russia. For example, a popular newspaper of Kazakhstan "Express - K" builds whole pages of publications using reports of world news agencies. For example, page 4 of the newspaper "Express - K" dated October 8, 2013, is fully formed on the basis of reports of news agencies, there are three news stories from the news agency Interfax ("Scientists from the U.S. and Germany Will Receive the Nobel Prize in Medicine", "Scotland can not be separated from the UK", "Head of the Issyk-Kul Region Has Been Taken Hostage"), two stories - from the news agency Lenta.ru ("Bloomberg gives an apocalyptic forecast", "The UK Has Created an Analogue of FBI"), and one article is given with reference to the RBC ("Nicolas Sarkozy Has Been Acquitted of the Charges in the Case "Betancourt") [Newspaper «Express K», 2013 ]. 
On the background of falling circulations of newspapers and magazines around the world, reduction of mass media staff, a paused growth of audiences and readers, there is a significant success in the work of information agencies with economic orientation. Phenomenal success, for example, has been achieved by the news agency RosBusinessConsulting (RBC, Russia). They have a huge number of readers -20 million. This currently largest media holding started namely with the organization of the news agency, and today it is an example of successful quality media with its channel, newspaper, publishing center, and a news agency. No exaggeration to say that one of the reasons for the success of the media holding is a correct and successful strategy of functioning at the very beginning of activities of RosBusinessConsulting news agency.

A long time ago foreign countries included a paid content into the work of news agencies. Russia is preparing ground for this innovation. How it will be successful and popular is yet be to analyzed by researchers of media and Kazakhstan.

Currently researchers state the following: news agencies firmly occupy a strategically important place in the system of modern mass media and with full confidence can be attributed to quality media. However, even news agencies today face a lot of problems - it is frank plagiarism of materials from NA sites, a slow decline in the number of users, a growing dependence on advertising, but the main problem is the preservation and development of high quality content.

Let us understand which traditional principle of functioning remains an important determinant for the news agencies and which among the new is designated as an important trend in the development of the activities of news agencies?

Thus traditionally fundamental features of functioning are preserved in the activities of modern news agencies. Still $80 \%$ $90 \%$ of the information is supplied by news agencies and the main out-of-editorial source of news of many mass media are still agencies, and the basic principles of work are still authenticity, timeliness, objectivity, accuracy.

\section{New trends in the development of news agencies}

Let us distinguish some new trends of modern news agencies: new competitors showed up -

a) information networks that build their work by copying the principles and structure of functioning of agencies;

b) bloggers, stringers, the latter are sometimes used by news agencies themselves.

1. Often the material of agencies becomes subjected to fast-copying. Similar phenomena used to happen before, but in a less degree. Today, thanks to the Internet, there is an opportunity to copy without attribution.

2. Principles of agencies' activities are the same, but there is a small nuance: today accuracy is more important than efficiency, that is, the rush and the speed are not as important as before, and apparently because unverified or misleading information can lead to more serious consequences than ever before when there was no age of the Internet and social networks.

3. In activities of individual agencies there is a willingness to give only a picture without any verbal commentary. What it involves and what consequences it leads to is to be studied yet.

4. News agencies as brands of countries - today it is expressed stronger than before, which makes national governments secretly subsidize the work of such important and worldwide recognizable international agencies such as Reuters and the Associated Press. They now received hidden government subsidies. However, it did not spare Reuters from being sold at the end of 2000s to Canadian businessmen [Strashnov , 2012, P.61].

5. There is a weakening of social and political significance of news agencies, for example, TASS and Kazinform today have different priorities and work styles, or we should rather talk about a more hidden, latent form of politicization of news agencies.

6. There is a decrease in the demand for materials of agencies, for example, broadcaster CNN in 2007 broke its long-term contract with Reuters [Strashnov, 2012, P. 62].

7. Thereby there is a reorientation of the content, researchers should analyze reasons and consequences of these processes. 


\section{Traditional and new news agencies}

\begin{tabular}{|c|c|}
\hline News agencies in former times & News agencies today \\
\hline $\begin{array}{l}\text { 1. Lack of internet sites; a telegraphic method for } \\
\text { transmitting information }\end{array}$ & $\begin{array}{l}\text { 1. Availability of own sites, existence exclusively in the } \\
\text { Web }\end{array}$ \\
\hline 2. Information providers & 2. both providers and distributors \\
\hline $\begin{array}{l}\text { 3. The hierarchy of the basic principles of work: efficiency, } \\
\text { reliability, etc. }\end{array}$ & $\begin{array}{l}\text { 3. In the foreground - authenticity, and only then } \\
\text { efficiency, etc. }\end{array}$ \\
\hline 4. $80 \%$ of information is supplied by NA & 4. $80 \%$ of information is supplied by NA \\
\hline 5. Verbal information & 5. Verbal and visual information \\
\hline 6. Strict canonicity of genres & 6. Deviation from the canons of the genre hierarchy \\
\hline 7. NA are support services & $\begin{array}{l}\text { 7. NAs represent greater autonomy, broadening of } \\
\text { powers and functions }\end{array}$ \\
\hline 8. Focus on news gathering & 8. Focus on collection of exclusive news \\
\hline 9. Lack of direct contact with readers and consumers & 9. Direct access to personal smartphones and tablets \\
\hline $\begin{array}{l}\text { 10. Functions of gathering and presenting information to } \\
\text { mass media }\end{array}$ & $\begin{array}{l}\text { 10. Function of collecting, processing and disseminating } \\
\text { information }\end{array}$ \\
\hline 11. Lack of explicit publicist character & 11. Emergence of diverse topics in journalism \\
\hline 12. Absence of advertising & 12. Emergence of advertisements in a small amount \\
\hline 13. Absence of multimediality & 13. multimediality \\
\hline 14. Absence of archiving & 14. ability to archive and increase memory \\
\hline 15. Absence of hypertext features & 15. hypertext features \\
\hline 16. Absence of interactivity & 16. interactivity \\
\hline 17. entertainment in mediated form & 17. Emergence of entertaining columns \\
\hline
\end{tabular}

At the same news agencies have to face the same problem, which should be solved by all the media in the new conditions of the postmodern era. News pollution and information noise, global locality, struggle for ratings and quality of published material - all of these represent only a part of everyday problems that are fast growing year after year. We should particularly single out the negative trend - a marked decrease in demand of individual media for materials of news agencies. Today it results in a reduction of staff journalists in Western countries. This phenomenon can be related to the activities of bloggers, stringers, reports that in their competition with Google French newspapers, for example, "decided to create their own news aggregator" [Strashnov, 2012]. So, despite the successful development of new features of functioning by news agencies we can observe an important challenge - the problem of the competitiveness of news agencies. This challenge should be seriously studied by media researchers.

\section{Global challenges of the media and news agencies}

In the face of new challenges of global media, news agencies should be considered as it was offered by V. Levchenko [2012] in three different aspects - ethical, technological and social.

Among ethical challenges the most important are not only the problems of global localization, availability of equal access to information, information pollution, but also the relation of form and content, the quality of transmitted information, shadow fusion with PR and advertising, following media ethical imperative, a core set of ethical principles of journalism.

Global locality manifests itself in close cooperation between with today's news agencies and business. We have seen in many successful foreign companies which in just a two or three-year period of time grow from small sites into huge media holdings. This allowed Barbara Gibson, a member of IABC, to make the following generalization: "The business model of 
the XXI century: from start-up to a global media company in 1-3 years" [Levchenko, 2012]. Among Russian examples we can single out the history of the development of RBC which started as a small news agency and is today a huge media holding with its own bank, TV channel, newspapers, and magazines. We cannot yet find a similar example in Kazakhstan. As to development of news agencies, we can only refer to the successful development of business media under the leadership of Oleg He. Perhaps the outlined slowing in the development of Kazakhstani business media is related to this miscalculation - disregard for Internet capabilities.

Global locality manifests itself in a much greater demand for news feeds of news agencies and mass media of post-Soviet countries by foreign consumers. For example, the audience of "The Moscow News" is represented by $60 \%$ by foreign readers. We cannot say anything similar about Kazakhstani editions, published in English or about newswires of agencies of Kazakhstan. At the same time it goes without saying that the foreign audience of Kazakhstani news sites has significantly grown thanks to online publications as well as English versions of sites of news agencies.

Equal access to information has spawned a whole set of new problems. As an example let us take the problem of perception of information. There has been coined a term "brain pollution" which means a negative impact of information on people and the effect of reducing their intellectual level. The famous foreign media researcher Ann Wylie, a member of IABC, notes that 4 out of 10 Americans do not know how to correctly perceive the information they have read. For a $100 \%$ perception of information words should consists of a maximum five letters and sentences - of 8 words. Out of 30 million of readers only $14 \%$ can correctly perceive information, out of 95 million - only $44 \%$ []. And this is a very serious problem for both journalists and consumers of information. In an age of equal access to information any misinterpreted news instantly generates a wave of financial and political cataclysms.

Information noise generates information pollution. It is in the work of news agencies and their intermediaries that we can observe a special diversity in mews presentation, when it is difficult to distinguish the important from the unimportant, when the visual dominates the verbal. All this creates a special effect of information noise. It becomes compounded also due to the fact that new media users can themselves share and transmit information to each other.

Among technological challenges we should highlight universal gadgetization, cross-, trans-, and multimediality of mass media, virtualization of global brands [ Levchenko, 2012].

Social challenges, according to $\mathrm{V}$. Levchenko represent a growth of new information intermediaries, the convergence of media and press services, futurological forecasts of the future of professions of a journalist and a communicator. A new trend singled out by V. Levchenko in the mass media is "press-realization of mass media", for example, in the UK agencies $70 \%$ of news stories are published on the basis of press releases [Levchenko, 2012]. News agencies now have new information intermediaries - aggregators, social networks and search engines, which greatly influenced the style of work. Social networking has resulted in a range of visitors of news agencies' sites and this can be seen as a positive trend of the development of media. However search engines often copy news stories of news agencies without attribution.

\section{Conclusions}

So, news agencies still remain the main suppliers of news and many of them are successfully developing. At the same time today we have to face very difficult problems of functioning in modern conditions - copyright, hacker attacks, complex financial problems, impoverishment of news sources, the need for constant search for new ways of functioning and information retrieval, frank plagiarism of materials from sites of news agencies.

Professor of the University of Amsterdam Cees Hamelink [2009] notes that the process of development of new media "launches new and challenging questions about the future of human communications". There is an original aphorism by M.G. McLuhan [1959]: "medium is the message".

One cannot ambiguously treat these phenomena of modern journalism. Excessive disregard of forms of traditional media may have currently caused an unrestrained passion for too loose reconstructions and reinterpretations and remixing of any information. Thereupon it is necessary to review the basic principles of work of news agencies - the not speed and quantity, but accuracy and quality of the material. But while many agencies still consider as the most important the principle of efficiency and the number of news replacement per unit time. For example, managers of the Kazakhstani agency Bnews require from their young journalists to produce 100 news stories every day. 
In modern news agencies there is an attraction to the formats of news flashes which contribute to the rapidity of posting information. However there is an increasing tendency to expand genre varieties, analytics and commentary which help to attract a greater number of permanent and serious users of sites.

Agencies are increasingly expanding the multimedia capabilities of their content.

News agencies have not escaped the trend of increased infotainment. Entertainment features which were previously not peculiar to news agencies, today occupy an important place in the discourse-news content. However, a lot of big agencies here try to diversify and deepen their material.

Many world-famous agencies manage to avoid explicit shadow merger with PR and advertising, but the problem of media framing of reality is urgent for journalists working with news texts. Influence of consumerism and "digital division" is also an urgent problem for modern agencies.

In general, many news agencies of worldwide fame are in the lead in today's modern media system. This is evidenced by innovations which accompany their activities. For example, it was reported that the state news agency Xinhua has filed an application for IPO (Initial Public Offering) of its site Xinhua.net at the exchange in Shanghai. This is informed by Reuters with attribution to the data of China Securities Regulatory Commission. Xinhua plans to raise about one billion yuan (177.8 million dollars) [Reuters]. This placement will become one of the largest IPO in the modern media industry and promises the agency new levels of development in the global media system.

One of the latest shocking news was the announcement that within three months one of the best agencies in Russia - RIA Novosti will be reorganized, the leadership of the agency will be changed as well as its name. Researchers believe that it happened chiefly due to the excessively independent position of RIA Novosti, despite the fact that they were fully financed by the state.

RIA Novosti in the past years has been an evident leader of the mass media not only in the post-Soviet space. They have also successfully competed with foreign agencies of worldwide fame, setting an example of creative initiative, creativity, and a constant search for ways to improve the forms of news and comments. This will certainly cause significant damage not only to the Russian media, but also to all the media of the post-Soviet and global space.

\section{References}

Baudrillard J. (1981). Simulacres et simulation, Galilée.-Paris.- P. 10.

Hamelink C. (2009). - James Halloran Memorial Lecture. Conversations with my Robot // Nordicjm Reviev/-V/30, June.Jubilee Issue. - P. 219

Levchenko V. (2012). Challenges of Global Media Communications. Presentation called "Challenges of Global Media Communications" in the framework of the Plenary session of VII Forum of European and Asian media (Minsk, 10-11 Dec. 2012) // http://www.slideshare.net/valerylev/ss-15602016

McLuhan M. (1959). Myth and Mass Media // Daedalus. Journal of the American Academy of Arts and Sciences.-V88/- № 2. - P. 340

Newspaper «Express K», (2013). 8 October, P. 4.

Nordicom Review.-2008.-V.2. № 29, November. Special Issue, P. 87-89

Strashnov S.L. (2012) Topical media notions. Ivanovo, Ivanovo State University, P. 60-63

Toffler A. The Third wave.- N.Y. 1980.- P.183

Uillok D.Э. 2000. Reality as a matter of negotiation: our understanding of chaotic attractors. - Moscow. - P.32

Vartanova Ye. L. (2013). Plenary statement at the International scientific-theoretical conference "Journalism in the year 2012: social mission and profession" // www.journ.msu.ru/about/news/7302

http://www.bnews.kz, http://tengrinews.kz/, http://itar-tass.com/, http://www inform.kz , russian.news.cn, www.rbc.ru http://www.reuters.com/, http://www. ria.ru 